\title{
Quantification method for elemental bio-imaging by LA-ICP-MS using metal spiked PMMA films
}

\author{
Christine Austin, Dominic Hare, Tristan Rawling, Andrew M. McDonagh and Philip Doble*
}

\author{
Received 9th June 2009, Accepted 10th December 2009 \\ First published as ân Advance Article on the web 14th January 2010 \\ DOI: $10.1039 / \mathrm{b} 911316 \mathrm{a}$
}

\begin{abstract}
A method for quantitative analysis of biological soft tissues by laser ablation-inductively coupled plasma-mass spectrometry has been developed. Polymer film standards were produced by spin coating spiked solutions of polymethylmethacrylate on to quartz substrates. Calibration curves throughout the range of $0-400{ }^{\circ} \mathrm{g} \mathrm{g} \mathrm{g}^{-1}$ yielded correlation coefficients better than 0.999 for ${ }^{66} \mathrm{Zn}$ and ${ }^{63} \mathrm{Cu}$. Spiked, homogenised soft tissue standards were quantified by LA-ICP-MS against the thin film standards. The results agreed with values calculated from solution nebulisation ICP-MS. A procedure for internal standardisation by employing ruthenium or yttrium in the underlying thin film was also assessed.
\end{abstract}

\section{Introduction}

Interest in determining elemental and molecular distributions in biological specimens has increased significantly in recent years. ${ }^{1}$ Trace metals are vital for many organisms and a deficit or excess may cause disease or toxic reactions. Spatially resolved concentration maps of trace elements in cells or tissue samples can therefore provide new and useful information. ${ }^{2}$

Laser ablation-inductively coupled plasma-mass spectrometry (LA-ICP-MS) is a suitable technique for the elemental analysis of biological specimens. ${ }^{3-5}$ LA-ICP-MS has multi-element and isotopic capability, large dynamic range, high sensitivity and quantitative response., ${ }^{2,6}$ Maps can be constructed that reveal elemental spatial distributions within biological samples at trace and bulk levels with lateral resolution on the micron scale. A recent review by Becker et al. ${ }^{1}$ describes some applications of LAICP-MS to bio-imaging and proteomics.

The use of LA-ICP-MS for quantitative biological and medical research requires suitable quantification procedures. ${ }^{1,2,7}$ Strategies developed for quantification include; preparation of matrixmatched laboratory standards, solution-based calibration, ${ }^{8-10}$ calibration using certified reference materials (CRMs), ${ }^{11-13}$ and direct independent measurement of mass ablated by light scattering ${ }^{14-18}$ or other techniques. ${ }^{19-23}$ Each of these methods, however, has drawbacks. Calibration using matrix-matched standards accounts for variations in the laser/sample interaction associated with different sample matrices. ${ }^{24}$ Homogenised tissue standards have been used for the quantification of tissue samples by LA-ICP-MS ${ }^{5,10,25-27}$ however preparing the matrix-matched standards is time consuming and sometimes difficult. ${ }^{9,28}$

Becker $e t$ al ${ }^{\text {io }}$ described a solution-based LA-ICP-MS caljbration to validate matrix-matched laboratory standards used to quantify elements in human brain samples. The method uses easily obtained standard solutions for calibration and matched the precision of standards ${ }^{9}$ although it does not account for

Elemental Bio-imaging Facility, Department of Chemistry and Forensic Science, University of Techmology Sydney, Sydney, NSW, 2007. Australia. E-mail: philip.doble@uts.edu.au; Fax: +612 9514 1460; Tel: $+61295141792$ variations that may occur during the laser sampling process. ${ }^{23}$ Additionally, the different forms in which the sample (ablated particles) and reference material (liquid aerosol) enter the ICPMS may exacerbate matrix effects and the dilution of the ablation stream with the nebulised stream of standard material may decrease sensitivity. ${ }^{29}$

In the case of CRMs, these are often not available for the analyte of interest or at the required concentration ranges.

Other approaches have utilised standardless, independent methods to directly measure ablated mass. These include light scattering ${ }^{14-18}$ and acoustic wave generation ${ }^{19,20}$ techniques as well as total sum of signal normalisation ${ }^{21,22 .}$ and piezoelectric microbalances. ${ }^{23}$ Signal sum normalisation techniques require the simultaneous acquisition of all elements from the transient signal and assume that the sum of those elements equals the mass ablated, giving semi-quantitative information at best. Precision comparable to that achieved when using an internal standard (IS) has been reported by some users of the techniques listed above ${ }^{14-18}$ but these methods add complexity, cost and time to an otherwise straightforward technique. ${ }^{22}$

This article presents a new method for quantification of biological soft tissue samples by LA-ICP-MS based on spin coated calibration standards. Fig. 1 illustrates the concept of ablation of the sample together with a film containing ISs.

Spin coating is a process widely employed for fabrication of thin film coatings with high structural uniformity. ${ }^{30}$ Chi et al. ${ }^{31}$ quantified impurities in semiconductor photoresists by LA-ICPMS using calibration standards prepared by spin coating and quantified after microwave digestion by solution nebulisation (SN) ICP-MS. Ryu et $a l^{32}$ used a similar technique to fabricate

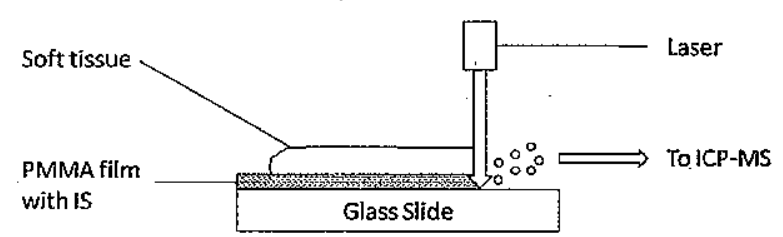

Fig. 1 Internal standard scheme for elemental bio-imaging. 
calibration standards to measure metal impurities in thin layers on silicon wafers:

Importantly, the work presented here includes a normalisation technique for LA-ICP-MS of biological soft tissues, which is required to account for variations in ablated mass. The majority of bio-imaging studies by LA-ICP-MS have normalised analyte signals to ${ }^{13} \mathrm{C}$ as an IS. Carbon-13 is often (but not always) homogenously distributed within biological soft tissues however it does not entirely satisfy the conditions usually desired for an IS. Several LA-ICP-MS studies of soft tissue and polymer samples have found ${ }^{13} \mathrm{C}$ to be an unsatisfactory $\mathrm{IS} ;{ }^{13} \mathrm{C}$ was less sensitive to instrumental fluctuations than the analytes under investigation, ${ }^{11}$ showed heterogeneous distribution in tumours, ${ }^{33}$ and plasma behaviour differences between carbon and analytes. ${ }^{34}$ Although using carbon as an internal standard may improve precision compared to raw counts, ${ }^{12,13,31,35,36}$ an alternative IS that shows similar plasma and transport behaviour is highly desirable. ${ }^{37}$

\section{Materials and methods}

\section{Thin film preparation}

The workflow for the preparation of IS and calibration standard films is shown in Fig. 2. Quartz slides $(25 \times 25 \mathrm{~mm})$ were washed successively in acetone, $5 \%$ nitric acid solution and water (distilled and deionised by the Milli-Q system - $18.2 \mathrm{M} \Omega \mathrm{cm}$ ). Glass vials used for preparation and storage of spin solutions were acid washed overnight in $30 \%$, then $5 \%$ nitric acid before rinsing with Milli-Q water and baking dry.

Poly(methylmethacrylate) (PMMA) with average molecular weight $~ 996000$ (Aldrich, Germany), chlorobenzene $(99.8 \%$, Sigma-Aldrich, Germany), m-xylene ( $+99 \%$, Sigma-Aldrich, Germany) and 1000 ppm metallo-organic standards (High Purity Standards, USA) were used as received. The ruthenium phthalocyanine dye, $\left[\left\{t-\mathrm{Bu}_{4} \mathrm{Pc}\right\} \mathrm{Ru}(4-\mathrm{Bupy})_{2}\right]$, was synthesised from $\left[\left\{t-\mathrm{Bu}_{4} \mathrm{Pc}\right\} \mathrm{Ru}(\mathrm{PhCN})_{2}\right]$ and 4 -tert $t$ butylpyridine using the literature procedure. ${ }^{38}$

For calibration curves, standards were spin coated from solutions of PMMA $(10 \%)$, xylene $(40 \%)$, and chlorobenzene $(50 \%)$ and spiked with organometallic $\mathrm{Cu}$ and $\mathrm{Zn}$ standards at 0 , $1,5,10,15,20$ and $30 \mu \mathrm{g} \mathrm{g}^{-1}$. Ruthenium phthalocyanine dye and

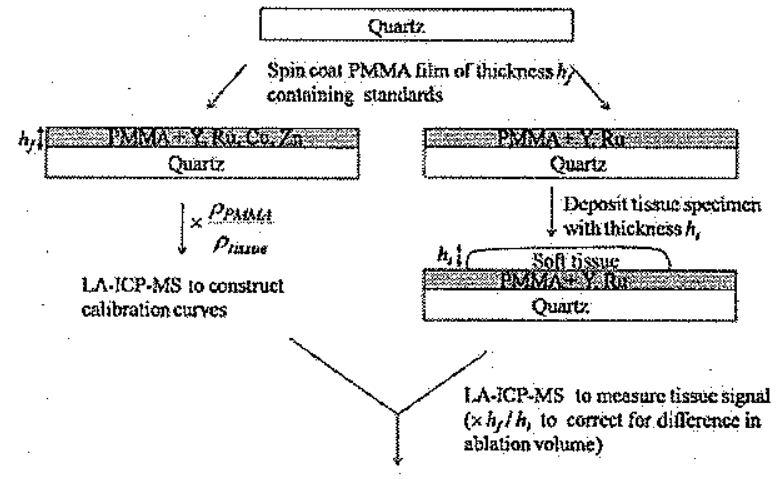

Quantitative tissue Cu concentration (ap/g tissue)

Fig. 2 Workflow of the quantification process with film standards. an organometallic yttrium standard were also added (at $1 \mathrm{mg} \mathrm{g}^{-1}$ and $2 \mu \mathrm{g} \mathrm{g}^{-1}$ respectively) to be used as ISs.

Clean slides were placed on the vacuum chuck of a single wafer spin processor; model WS-400A-6NPP/LITE (Laurell Technologies Corporation, USA) and $200 \mu$ of the spin solution deposited on the slide using a micropipette. The solution was allowed to sit for $10 \mathrm{~s}$ before accelerating to $4000 \mathrm{rpm}$ for $40 \mathrm{~s}$. Substrates were then baked on a hot plate at $130 \pm 1{ }^{\circ} \mathrm{C}$ for $2 \mathrm{~min}$.

\section{Thin film characterisation}

After spin coating, the slide was placed in a UV-Vis spectrophotometer (Agilent 8453, model G1103A) and the spectrum recorded. Additionally, a section of the substrate was removed using a diamond tip pen and the film dissolved in chlorobenzene for solution UV-Vis analysis. Film thickness was measured by profilemetry (Alpha-Step 100, Tencor Instruments). Surface roughness was characterised by atomic force microscopy (AFM) (Dimension $^{\mathrm{TM}} 3100$ SPM, Digital Instruments).

\section{Preparation of tissue standards}

Standardised soft tissue samples were prepared in the same manner as reported by Hare $e t \mathrm{al}^{39}$ Briefly, two chicken breast tissue samples (S1 and $\mathrm{S} 2$ ) were prepared by spiking known amounts of copper ( 5 and $10 \mu \mathrm{g} \mathrm{g}^{-1}$ ) and zinc ( 8 and $13 \mu \mathrm{g} \mathrm{g} \mathrm{g}^{-1}$ ). The chicken breast was then homogenised and aliquots ( $c a$. $100 \mathrm{mg}$ ) quantified by microwave acid digestion and SN-ICP-MS with $Y$ added as an IS via a T-piece (Table 1).

To prepare samples for LA-ICP-MS analysis, the spiked soft tissue samples were frozen and slices precisely cut at $20 \mu \mathrm{m}$ thickness and placed on top of spin coated quartz slides containing yttrium (2 $\mu \mathrm{g} \mathrm{g}^{-1}$ ) and ruthenium phthalocyanine $\left(1 \mathrm{mg} \mathrm{g}^{-1}\right)$. The prepared soft tissue samples were then quantified by LA-ICP-MS using the calibration curves from the spin coated standards.

\section{LA-ICP-MS}

A New Wave (Fremont, CA, USA) UP213 laser ablation unit, coupled to an Agilent Techriologies 7500cs Series ICP-MS was used to analyze the thin films. The laser system was a Nd:YAG laser operating at the fifth harmonic frequency $(213 \mathrm{~nm})$ with a repetition frequency of $20 \mathrm{~Hz}$ and beam area of $65 \mu^{2}$. The laser was operated at $30 \%$ power density giving $\sim 0.1 \mathrm{~J} \mathrm{~cm}^{-2}$ and scanned across the sample at a speed of $15 \mu \mathrm{m} \mathrm{s}^{-1}$. The sample and standard slides were mounted on an $x-y-z$ translation stage, which could be manipulated using a computer and monitored by CCD camera. The ablated material was transported to the ICPMS by argon carrier gas. Analytes and ISs $\left({ }^{13} \mathrm{C},{ }^{63} \mathrm{Cu},{ }^{66} \mathrm{Zn},{ }^{89} \mathrm{Y}\right.$ and ${ }^{0 !} \mathrm{Ru}$ ) were monitored by the ICP-MS (Rf Power $1300 \mathrm{~W}$, carrier gas flow $1.15 \mathrm{~L} / \mathrm{min}$, plasma gas flow $15 \mathrm{~L} / \mathrm{min}$, dwell time $100 \mathrm{~ms}$, scan mode; peak hopping).

\section{Data analysis}

Variations across line scans were assessed using relative standard deviations (RSD). RSDs were calculated as the ratio of standard 
Table 1 Concentrations ( $\mu \mathrm{g} \mathrm{g}^{-1}$ ) of $\mathrm{Cu}$ and $\mathrm{Zn}$ in soft tissue samples

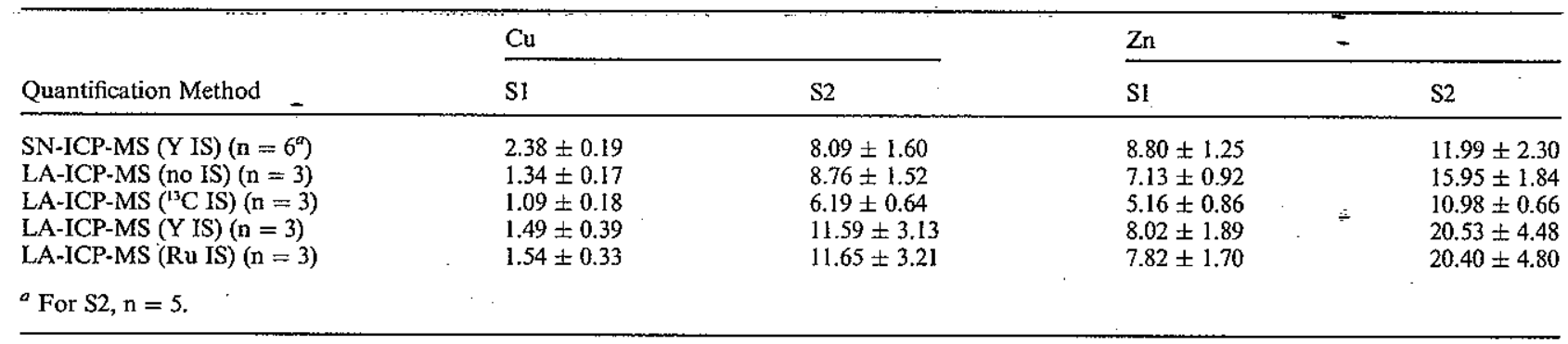

deviation of raw counts to the mean of raw counts of the line scan data and then converted to a percentage.

Evaluation of LA-ICP-MS IS methods was facilitated by comparing mean concentration values with those obtained by SN-ICP-MS by-an independent two-tailed t-test at the $95 \%$ confidence interval, using Microsoft Éxcel. Añ F-test was first applied to determine the use of variances equal or unequal t-tests. A $p$ value less than 0.05 was considered statistically significant and the null hypothesis that the means were the same was rejected.

\section{Results and discussion}

To demonstrate the new method for quantification by LA-ICPMS based on spin coated calibration standards we analysed $\mathrm{Cu}$ and $\mathrm{Zn}$ concentrations in standardised, homogenised, soft tissue samples. $\mathrm{Cu}$ and $\mathrm{Zn}$ were investigated as examples of elements commonly found in trace amounts in biological soft tissues, however the method is applicable to any element available in an organic-şolıble medium.

A ten-fold increase in analyte concentration in the film compared to the spin coating solution was expected due to solvent evaporation. This was confirmed by UV-Vis spectroscopy which was used to determine the change in concentration of the dye. Thus, the films contained $0,10,50,100,150,200$ and $300 \mu \mathrm{g} \mathrm{g}{ }^{-1} \mathrm{Cu}$ and $\mathrm{Zn}$.

The composition of the spin coating solution and spin rate had a significant influence on film thickness and uniformity. The composifion described here was found to be optimum and yielded films of $\sim 1 \mu \mathrm{m}$ thickness with less than $2 \%$ variance across the film (measured by profilometry). A surface roughness of $\sim 10 \mathrm{~nm}$ was measured by atomic force microscopy. This variation of the film surface was insignificant given the micrometer resolution of $\mathrm{LA}$.

The calibration plots of zinc and copper showed good linearity over the range $0-300 \mu \mathrm{g} \mathrm{g}^{-1}$ with correlation coefficients better than 0.999 with ${ }^{89} \mathrm{Y}$ or ${ }^{101} \mathrm{Ru}$ normalisation. The ruthenium phthalocyanine dye was relatively concentrated compared to trace elements commonly found in soft tissue samples so was considered a suitable IS for more concentrated elements while the yttrium was added for internal standardisation at a similar concentration to that expected for trace elements in biological soft tissues.

The spin coated calibration standards were assessed by comparison against standardised soft tissue samples. The data in Table 1. show agreement between the LA-ICP-MS and
SN-YCP-MS quantification for both $\mathrm{Cu}$ and $\mathrm{Zn}$. For standard S1, the amount determined by LA-ICP-MS was within 2 standard deviations for $\mathrm{Cu}$ and within one standard deviation for $\mathrm{Zn}$ when compared against SN-ICP-MS. For standard S2, the amount determined for $\mathrm{Cu}$ was within one standard deviation and for $\mathrm{Zn}$ within two standard deviations. It was expected that ${ }^{10} \mathrm{Ru}$ would not be a suitable IS for trace elements due to its much greater concentration. However, there were no significant differences between ${ }^{10 !} \mathrm{Ru}$ and ${ }^{89} \mathrm{Y}$.

The data in Table 1 and 2 show that although IS ${ }^{13} \mathrm{C}$ improves precision, quantification is less acurate than when using $\mathrm{Y}$ or $\mathrm{Ru}$ as ISs. Only $\mathrm{Zn}$ in $\mathrm{S} 2$ was accurately quantified $(p \geq 0.05)$ with ${ }^{13} \mathrm{C}$ normalisation. Conversely, quantification of $\mathrm{Cu}$ and $\mathrm{Zn}$ in $\mathrm{S} 1$ and $\mathrm{S} 2$ was not found to be significantly different between $\mathrm{Y}$ or $\mathrm{Ru}$ normalised LA-ICP-MS and SN-ICP-MS values. ${ }^{13} \mathrm{C}$ as an internal standard improved precision most likely due to the high background counts which were typically an order of magnitude higher than copper or zinc. The high background counts would also have decreased the accuracy of ${ }^{13} \mathrm{C}$ as an IS by masking the fluctuations in the ${ }^{13} \mathrm{C}$ signal due to the film and the sample.

When compared with LA-ICP-MS quantification without an IS, data normalised to $Y$ and $R u$ are less precise but the quantified values are closer to those determined by SN-ICP-MS. Therefore, $\mathrm{Y}$ and $\mathrm{Ru}$ ISs improve the accuracy of quantification by LA-ICP-MS when compared with no IS or with ${ }^{13} \mathrm{C}$ as an IS.

The larger standard deviations associated with LA-ICP-MS quantification may be attributed to the inherent limitations of solid sampling by laser ablation. Typical variations of normalised raw counts per second across line scans of the spin coated standards were less than $10 \%$ RSD. Soft tissue line scans generally showed variations of $10-20 \%$ RSD. The higher variation across soft tissue line scans was likely due to incomplete homogenisation of the sample and/or cracking of the surface.

Table 2 t-test results of comparisons of LA-ICP-MS against SN-ICP-MS

\begin{tabular}{llllll} 
& \multicolumn{2}{l}{$p$ value } & & \\
\hline & $\mathrm{Cu}$ & & $\mathrm{Zn}$ & \\
\cline { 2 - 3 } LA-ICP-MS IS & $\mathrm{S} 1$ & $\mathrm{~S} 2$ & $\mathrm{~S} 1$ & $\mathrm{~S} 2$ \\
\hline no IS & $9.1 \times 10^{-5}$ & 0.73 & 0.084 & 0.046 \\
${ }^{13} \mathrm{C}$ & $2.6 \times 10^{-5}$ & $2.0 \times 10^{-6}$ & $3.0 \times 10^{-3}$ & 0.50 \\
$\mathrm{Y}$ & 0.063 & 0.19 & 0.57 & 0.055 \\
$\mathrm{Ru}$ & 0.027 & 0.24 & 0.45 & 0.065 \\
\hline
\end{tabular}


This cracking was a consequence of the removal of water from drying the frozen tissue sections prior to LA-ICP-MS. The higher RSDs due to laser sampling and soft tissue standard preparation resulted in a higher degree of variation in the LA-ICP-MS quantification method when compared with SN-ICP-MS.

\section{Conclusions}

Film standards fabricated by spin coating spiked solutions onto quartz slides were used to quantify copper and zinc in a homogenised soft tissue sample. The spin coating parameters and solution composition were optimised to achieve good film homogeneity and uniformity. The polymer matrix ablated in a similar fashion to soft tissue samples as demonstrated by close agreement in the determined values of homogenised soft tissue samples, previously quantified by SN-ICP-MS after acid microwave digestion. The spin coating approach to quantification of soft tissues by LA-ICP-MS offers a much simpler, faster and more reliable method than homogenised tissue standards.

\section{Notes and references}

1 J. S. Becker, M. Zoriy, J. S. Becker, J. Dobrowolska and A. Matusch, J. Andl. At. Spectrom, 2007, 22, 736-744.

2 R. Lobinski, C. Moulin and R. Ortega, Biochimie, 2006, 88, 15911604.

3 S. F. Durrant and N. I. Ward, J. Anal. At. Spectrom., 2005, 20, 821829

4 J. S. Becker, M. Zoriy, J. S. Becker, J. Dobrowolska, M. Dehnhardt and A. Matusch, Phys. Status Solidi C: Curr. Top. Solid State Physics, 2007, 4, 1775-1784.

5 J. Dobrowolska, M. Dehnhardt, A. Matusch, M. Zoriy, N. PalomeroGallagher, P. Koscieiniak, K. Zilles and J. S. Becker, Talanta, 2008, 74, 717-723.

6 H. Haraguchi, J. Anal. At. Spectrom, 2004, 19, 5-14.

7 N. I. Ward, S. F. Durrant and A. L. Gray, J. Anal. At. Spectrom., $1992,7,1139-1146$.

8 D. Guenther, H. Cousin, B. Magyar and I. Leopold, J. Anal. At. Spectrom., 1997, 12, 165-170.

9 J. J. Leach, L. A. Allen, D. B. Aeschliman and R. S. Houk, Anal. Chem, 1999, 71, 440-445

10 J. S. Becker, M. V. Zoriy, C. Pickhardt, N. Palomero-Gallagher and K. Zilles, Anal. Chem., 2005, 77, 3208-3216.

11 B. Jackson, S. Harper, L. Smith and J. Flinn, Anal. Bioanal. Chem., 2006, 384, 951-957.

12 A. Kindness, C. N. Sekaran and J. Feldmann, Clin. Chem., 2003, 49, 1916-1923.
13 J. Feldmann, A. Kindness and P. Ek, J. Anal. At. Spectrom., 2002, 17, 813-818.

14 R. J. Watling, J. Anal. At. Spectrom., 1998, 13, 927-934.

15 S. A. Baker, B. W. Smith and J. D. Winefordner, Appl. Spectrosc., $1998,52,154-160$

16 P. Richner, M. W. Borer, K. R. Brushwyler and G. M. Hieftje, Appl. Specirosc., 1990, 44, 1290-1296.

17 H.-R. Kuhn and D. Guenther, J. Anal. At. Spectrom., 2006, 21, 1209 1213.

18 T. Tanaka, K. Yamamoto, T. Nomizu and H. Kawaguchi, Anal. Sci., $1995,11,967-971$

19 G. Chen and E. S. Yeung, Anal. Chem., 1988, 60, 2258-2263.

20 H. M. Pang, D. R. Wiederin, R. S. Houk and E. S. Yeung, Anal. Chem., 1991, 63, 390-394.

21 C. Latkoczy, Y. Mueller, P. Schmutz and D. Guenther, Appl. Surf. Sci. 2005, 252, 127-132.

22 A. M. Leach and G. M. Hieftje, Anal. Chem., 2001, 73, 2959-2967.

23 D. B. Aeschliman, S. J. Bajic, D. P. Baldwin and R. S. Houk, J. Anal. At. Spectrom., 2003, 18, 872-877.

24 R. E. Russo, X. Mao, H. Liu, J. Gonzalez and S. S. Mao, Talanta, 2002, 57, 425-451.

25 M. Zoriy, A. Matusch, T. Spruss and J. S. Becker, Int. J. Mass Spectrom., 2007, 260, 102-106.

26 J. S. Becker, M. V. Zoriy, M. Dehnhardt, C. Pickhardt and K. Zilles, J. Anal. At. Spectrom., 2005, 20,912-917.

27 J. S. Becker, A. Matusch, C. Depboylu, J. Dobrowolska and M. V. Zoriy, Anal. Chem., 2007, 79, 6074-6080.

28 C. Pickhardt, J. S. Becker and H.-J. Dietze, Fresenius J. Anal. Chem., $2000,368,173-181$

29 D. Gunther, S. E. Jackson and H. P. Longerich, Spectrochim. Acta, Part B, 1999, 54, 381-409.

30 K. Norrman, A. Ghanbari-Siahkali and N. B. Larsen, Annu. Rep. Prog. Chem., Sect. C, 2005, 101, 174-201.

31 P.-H. Chi, F.-H. Ko, C.-T. Hsu, H.-L. Chen, C.-K. Yang, Y.-C. Sun and M.-H. Yang, J. Anal. At. Spectrom, 2002, 17, 358-365.

32 W. K. Ryu, J. S. Kim, J. S. Lee, H. B. Lim and P. K. Jun, J. Anal. At. Spectrom., 2007, 22, 623-629.

33 M. V. Zoriy, M. Dehnhardt, A. Matusch and J. S. Becker, Spectrochim. Acta, Part B, 2008, 63B, 375-382.

34 J. L. Todoli and J. M. Mermet, Spectrochim. Acta, Part B, 1998, 53B, $1645-1656$.

35 E. Hoffmann, C. Leudke, H. Scholze and H. Stephanowitz, Fresenius J. Anal. Chem., 1994, 350, 253-259.

36 U. Narewski, G. Werner, H. Schulz and C. Vogt, Fresenius $J$. Anal. Chem, 2000, 366, 167-170.

37 J. Marshall, J. Franks, I. Abell and C. Tye, J. Anal. At. Spectrom., $1991,6,145-150$.

38 T. Rawling, H. Xiao, S.-T. Lee, S. B. Colbran and A. M. McDonagh, Inorg. Chem., 2007, 46, 2805-2813.

39 D. Hare, B. Reedy, R. Grimm, S. Wilkins, I. Volitakis, J. L. George, R. A. Cherny, A. I. Bush, D. I. Finkelstein and D. Doble, Metallomics, 2009, 1, 53-58. 